\title{
BETWEEN PROGRESS AND BACKWARDNESS. A LOOK AT THE HOUSING POLICY OF THE PERIOD OF THE PEOPLE'S REPUBLIC OF POLAND FROM THE SOCIAL AND ECONOMIC PERSPECTIVE AFTER 1989
}

\begin{abstract}
The article deals with the issue of the place, role and significance of the achievements of the housing policy of the Polish People's Republic (PRL) and in the economy before and after 1989, observed from the contemporary social and economic point of view. In the period of systemic transformation, expert and opinion-makers were, in majority, critical of the achievements of the housing policy of the prior period. This led to the creation and subsequent consolidation in public discourse of the negative image of the housing construction of the PRL period. 30 years after the collapse of communism, during which time the free market economy developed and Poland became a member of EU, this topic requires a more objective look and a more focused approach to the range of socio-demographic and economic changes that took place during that period. The current perception of the problem is also influenced by the lack of solutions to the housing issue by successive governments of the Third Republic of Poland.
\end{abstract}

Keywords: housing policy of the period of the Polish People's Republic, nationalisation of real estate, housing investments, modernization of housing estates, housing conditions in the public awareness after 1989

DOI: doi: 10.2478/sho-2020-0003

\section{INTRODUCTION}

Almost three decades have passed since the completion of the last housing estates in the so-called public housing. This lapse of time allows, as it seems, for a deeper reflection on post-war construction in general and the housing policy of the PRL period in particular. It turns out that in 
contemporary scientific and expert discourse, negative opinions and judgments about the housing policy of the PRL period prevail, which, however, should not shut down the discussion on this subject. This policy is frowned upon by both pro-market (belief in the miraculous and invisible hand of the market) and anti-statist (state interference in the economy is a threat to a return to the solutions previously applied in the socialist economy), which limits the broader and more nuanced view of the historical context to the origins and development of housing strategy from 19441989. The whole discussion on this subject would be of lesser importance if it were not for the fact that 30 years after the fall of communism, almost half the number of Poles live in housing estates from the period of the PRL, and the apartments from that period still play the biggest role in the real estate market. This means that the housing problems of Poles, which have been piling up since the partitions, have not been fully resolved since the collapse of the Polish People's Republic despite the reforms carried out in the country after 1989.

This article does not cover all issues concerning Polish housing policy in the 20th and 21st century. It is determined by the multi-facetedness and complexity of the subject matter. The author's intention is to present both the achievements and failures of the housing policy of the period of the PRL as well as the changes in its perception by historians, economists, experts and even inhabitants of post-PRL housing estates after the fall of communism in Poland.

\section{OUTLINE OF POST-WAR HOUSING POLICY IN POLAND}

Between 1944 and 1956, the communist authorities took over the main burden of managing politics and housing. The direct participation of the state in regulating housing relations was justified, at least initially, by the difficult economic situation in the country. Activities around housing focused on eliminating the effects of the damage due to war and rebuilding the pre-war housing stock. At the same time, the creation of a new housing order based on the new political system began [Andrzejewski A. 1979: 140]. The management of housing policy by means of numerous orders and prohibitions, i.e., tools of pressure and administrative-type control was a characteristic feature of this period. Until 1948, the communist authorities allowed for the existence of a private initiative in housing invest- 
ments and renovations, as well as the activity of housing cooperatives and associations. At the end of the 1940s, however, the authorities changed the course of their economic strategy and decided, for ideological and political reasons, to eliminate the influence of the cooperative and private sectors on housing policy. Consequent to these changes, between 1948 and 1956, the state became the most important investor in multi-family housing. As a result, a centralized economic institution called the Workers' Housing Estates Department was established [Zapart J. 1999: 29-30].

From the second half of the 1950s, there was a gradual move away from restrictive housing law and rationing of apartments in favor of greater freedom to dispose of private property. Most importantly, the state abandoned full subsidization of housing expenditures and reached for the population's own resources to relieve the burden of public spending on housing. This did not mean giving up various forms of subsidies, since the easily accessible and cheap state loan, granted on preferential terms to investors and future apartment users, was an important economic and financial stimulus in the development of housing after 1956. The housing cooperative was also brought back to social and economic life, which, however, was quickly subordinated to the objectives of the state housing development strategy. The changes described above were described in the Polish professional literature as a new housing policy [Kasperski W. 1963: 12, 16-7].

The decade 1961-1970 significantly changed the housing policy, as the size and structure of housing construction had changed. In the early 1960s, the state authorities temporarily abandoned the residential policy of 19561958 in favor of the implementation of investments in the so-called savings building. Technical and construction standards and prices for all forms of socialized housing construction were characteristic for this construction. As a result, the population inhabited apartments of an understated utility and technical standard. Contrary to the predictions of the ruling authorities of PRL, the solutions of savings building were not cheap at all, because higher than assumed labour costs and prices of building materials, based on building standards, forced the state to grant subsidies and loans.

In the 1970s, housing policy was still strongly linked to the processes of intensive industrialization and urbanization of municipal areas. In order to meet the growing housing needs of the population, the authorities resigned from the savings building system in favour of building apartments of higher urban and construction standards. First, there was an unprecedented quantitative leap in the number of apartments that were be- 
ing put into operation. Housing cooperatives became the main contractor for housing investments in the 1970s and 1980s, while individual buildings dominated in the countryside. Growing demographic pressure and the lack of keeping up with the housing needs of the population caused, in part, a return to the system of rationing new cooperative apartments. The economic crisis at the end of the 1970s started the collapse of investments in multi-family housing and then the regression of the whole housing policy in the last decade of the PRL.

In the case of housing, one of the main objectives of the transformation of the system (1989-2004) was to limit state interference in this sector. As a result of the economic reforms introduced, deregulation occurred, mainly, in the area of housing costs and rents, the commercialization of building materials industry and housing services. Moreover, support for property construction was launched and public subsidies were reduced. During the first years of these political changes, the housing policy was not directed towards the creation of a new housing system, however the construction investments started earlier were completed. The housing crisis of the mid-1990s forced the government to change its approach to housing and apply new solutions based on the experience of Western European countries. At that time, among other things, a mechanism of preferential lending to Housing Associations (TBS - Towarzystwa Budownictwa Mieszkaniowego) and housing cooperatives for building rentable apartments with moderate rents was launched. Their later participation in the structure of constructed apartments turned out to be small due to the lack of stable state support for social rental housing (e.g. liquidation of the National Housing Fund in 2009). The slow rebound from the collapse of investment was supported by the first development investments in that period and the development of commercial banking, which provided mortgages, including those in foreign currencies. It was then that various incentives appeared in the form of tax breaks (especially in the years 19932001) or preferential VAT rates for people buying or building apartments and houses and for construction materials and services [WęcłowowiczMuzioł A. 2015: 25]. The global financial crisis at the beginning of the XXI century, which was connected with the mortgage market in the USA, as well as the increase in foreign currency exchange rates, reduced residential investments in the country. By the second decade of the XXI century, when the situation of households' income improved, developers dominated the housing market in the form of new apartments with low investment activity of social, cooperative and municipal construction (municipalities) 
at the same time. Although the developer apartments built for consumption and investment purposes increased the pool of vacant apartments on the market, their prices also increased, leading to a surplus of apartments in relation to effective demand [Cesarski M. 2017: 91]. During this period, the state's actions were, mainly, limited to government programs that used indirect instruments for the financing of housing construction (periodic subsidies for housing loans, one-off financing for own contribution). At present, the government's activity in direct participation in housing investments on the scale of the entire market is very low, despite the fact that politicians at the helm of the government announced the construction of 100,000 cheap apartments for rent with an option of access to ownership in 2018 [Mieszkanie plus... 2019].

\section{BETWEEN PROGRESS AND SHORTAGE. ANALYSIS OF THE DYNAMICS OF QUANTITATIVE DEVELOPMENT OF HOUSING IN PRL AND THE III REPUBLIC}

After 1945, the housing industry struggled with enormous demand, caused by demographic pressure and economic migration of the rural population to the cities. During the period of the People's Republic of Poland, the population increased by 14 million people and the number of inhabitants in the cities increased from 32\% to 61\% [Raport. Stan mieszkalnictwa... 2020: 11]. The developmental dynamics of population growth was the highest in Europe from 1950-1980 (152.1\% growth). Therefore, it should not come as a surprise that from the very beginning, the solution of the housing issue had been one of the priority tasks of the state.

During the period of rebuilding the Polish state (1945-1949), the housing conditions of the population were among the worst in Europe, which should be acknowleged by all critics of the early post-war housing policy in Poland. Despite the enormous damage caused by the Nazi occupation, the housing situation of the population within the borders of the new state was more favourable than before the war. This was due to the large demographic losses (less by $28 \%$ of the Polish population) and the absorption of heavily urbanized post-German areas in the west, where there were larger apartments of a higher standard than those lost in the Eastern Borderlands. The colossal material havoc to the country was evidenced by the fact that cities such as Warsaw, Gdańsk, Wrocław or Szczecin had 


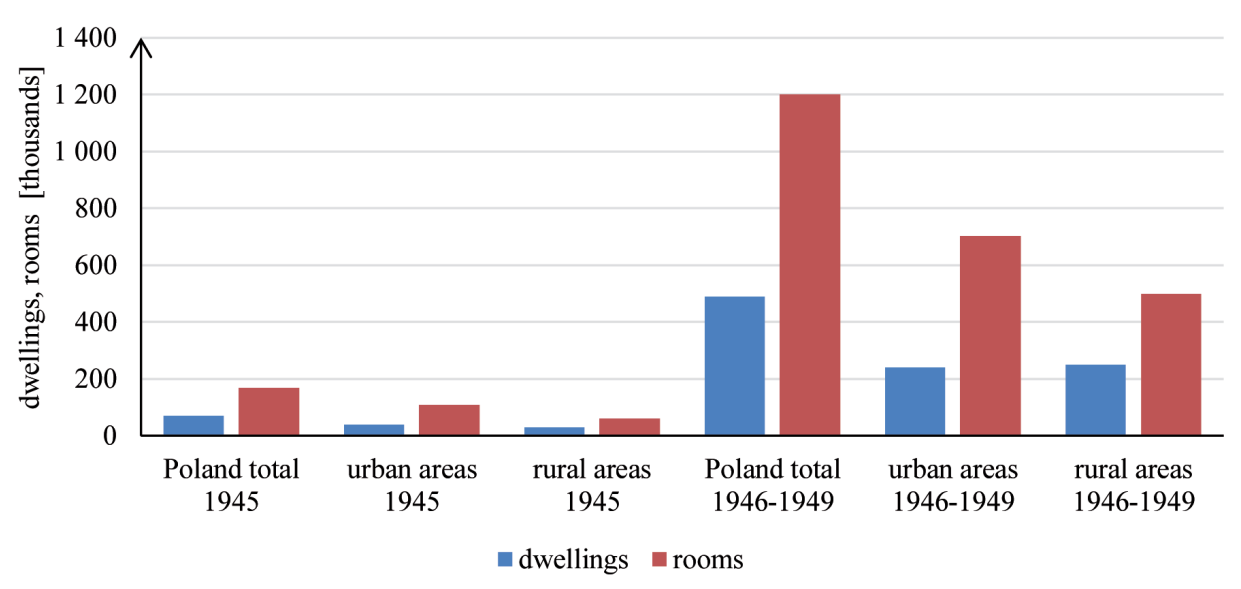

Figure 1. Dwellings and rooms put into service in 1945-1949 (thousands) Source: Frąckowiak M. [2008: 29].

to rebuild their urban fabric with the financial support of the entire society, which significantly slowed down the recovery of supra-regional socio-economic functions of these cities. In turn, the surviving housing stock in central and eastern Poland was usually in a poor technical condition, which was further compounded by the period of occupation and pre-war negligence in the form of a lack of modernization of residential buildings, especially those from before 1918. The large territorial disparities in the housing situation of the population was a characteristic feature of postwar housing. Statistically, the number of people per room in the occupied post-German areas was mostly one person less than in the other areas. This is also, where, on average, there were more rooms per apartment than elsewhere. In general, the housing conditions of the rural population were worse than in the cities, as evidenced by the lower standard and higher population of apartments. This does not change the fact, however, that in the years 1946-1949, a spontaneous construction action was undertaken in the countryside, as a result of which more apartments were built there than in cities (by 10,000), but with fewer rooms to be occupied (see Figure 1) [Frąckowiak M. 2008: 25-7].

In the period of PRL more apartments were built than in post-communist Poland. Just from 1950-1980, when the state industry was developing most intensively, more than 5 million apartments were put into use, which constitutes $69 \%$ of the total housing stock that had been created in socialist Poland. However, in the years 1991-2019, there was a significant decrease in the number of built apartments compared to the previous pe- 
riod: only 3.6 million apartments were built in Poland during that period, which is almost 30\% less than in the three comparable decades of 19501980. The record low rate of growth in the number of new apartments occurred in the last decade of the 20th century, when under the conditions of system transformation less than 900 thousand apartments were made available. In the People's Republic of Poland, the largest scale of housing investments took place in the 1970s, when industrialized housing construction began to develop, which commonly used the prefabricated large panel system in construction technology. The investment boom of that period resulted in the creation of large housing complexes in many Polish cities. In the years 1971-1978 about 242 thousand apartments, on average, were put into use every year (1978 was the record year when 283 thousand apartments were built). The economic collapse of 1979-1980 brought about a clear decrease in the number of dwellings built in the years that followed. In turn, after 1989, the largest traffic of construction in the residential sector fell in the years 2011-2019, when 161.5 thousand new apartments, on average, were put to use each year. The presented quantitative data shows that after the fall of the People's Republic of Poland, construction investors failed to relate to the record-breaking increase in the number of apartments from the 1970s, which marked the period of the highest intensity of housing investments. However, they only managed to achieve similar investment dynamics from the declining period of Polish People's Republic (only in 2017 did the housing market see the highest number of flats completed since 1988) [Efekty działalności..., 2018: 13].

In total, the People's Republic of Poland has settled 7.5 million of the population in new apartments. In post-war Western and Northern Europe, faster development of housing construction than in the Polish People's Republic was recorded only in Finland. Census data clearly indicate that during this period the general housing situation of the population improved, as the number of new apartments and rooms increased, and consequently the number of people per room and apartment fell. Nevertheless, the high dynamics of housing investments with a large increase in households did not eliminate the shortage of apartments. Despite a huge investment effort in socialist Poland, there were still fewer apartments per 1000 inhabitants than even in poorer countries of southern Europe (Portugal, Spain, Greece). In this situation, Poland, as a country of economic shortage, showing several decades of technological backwardness, was not able to match the Western European countries in terms of the size of its resources and housing standard. It should be noted, howev- 


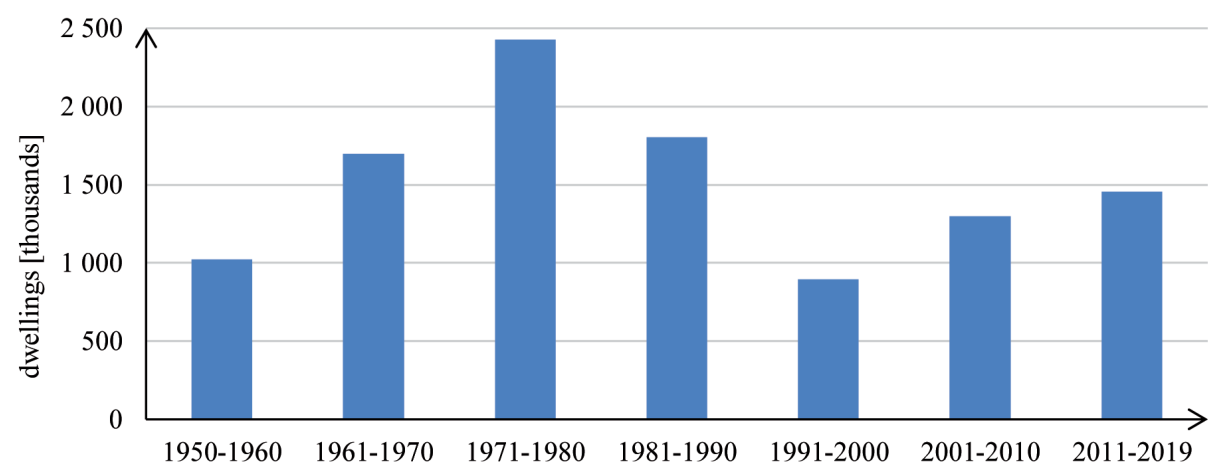

Figure 2. Number of dwellings completed in Poland in the years 1950-2019 (thousands)

Source: Efekty działalności... [2018: 13]; Frąckowiak M. [2008: 158-9]; Zapart J. [1999: 34]; Andrzejewski A. [1977: 73].

er, that in many European countries, the scale of housing arrears, resulting from the neglect of the pre-1939 period and the destruction caused by the war period, has been much smaller than in Poland.

Due to the dynamic growth of the urban population, most of the national residential investments were made in industrial centers. In the countryside, individual constructions developed with some difficulties, and it was not until the 1970s and 1980s that the state authorities began to influence the urban and spatial shape of the countryside to a greater extent, mainly, in towns related to the activities of the State Agricultural Farms (PGR). The direction of housing policy chosen by the state caused the housing situation of the rural population to look worse than in cities at the end of the Polish People's Republic; however, the common feature of the development of urban and rural construction was the housing deficit. Compared to urban societies, there were fewer apartments per 1,000 inhabitants (254), while rural dwellings were also more overcrowded (3.97 people per 1 flat/1.11 people per room), despite the fact that they had a larger usable area (by $15.3 \mathrm{~m}^{2}$ ) and the resulting larger usable area of 1 apartment per person (by $0.6 \mathrm{~m}^{2}$ ). On the other hand, the independence of the apartment (112) was at the same level [Frąckowiak M. 2008: 57]. Between 1988 and 2018, the average usable floor area of an apartment increased by a total of $15.1 \mathrm{~m}^{2}$, and about $24.7 \mathrm{~m}^{2}$ in rural areas, while it increased in the cities by only $10.9 \mathrm{~m}^{2}$. In cities, the usable floor area of the stock increased per capita from $16.8 \mathrm{~m}^{2}$ in 1988 to $27.7 \mathrm{~m}^{2}$ in 2018 . (in the rural areas, it increased from $17.4 \mathrm{~m}^{2}$ to $29.01 \mathrm{~m}^{2}$ ). In contrast to almost 
the entire period of the People's Republic of Poland, the increase rate of usable floor space per person after 1989 is only slightly lower in the cities than in the countryside. The changes are a result of the increase in the size of apartments primarily in less overcrowded cities due to the liquidation of the state urban planning standard in 1988 and the construction of numerous larger-sized developer apartments. Although there is a gradual decrease in the density of apartments, the problem of overcrowded housing still affects the rural areas more than cities. In 2018, the total number of people per apartment/ chamber is 2.63/0.69 (in 1988: 3.46/1.02 respectively). In rural areas, there are 3.23 persons per apartment ( 0.74 persons per chamber), while in cities there are only 2.34 persons ( 0.66 person per chamber) [Raport. Stan mieszkalnictwa... 2020: 35; Cesarski M. 2011: 10, 13].

The statistics of independent living, treated by experts as the main indicator of housing needs - throughout the whole period of the Polish People's Republic, indicated a gradual improvement in access to housing for Poles. Nevertheless, in 1988 this indicator was 112.0, which means that the number of households exceeded the available number of dwellings. The statistics of independent living, despite less demographic pressure, did not improve significantly after 1989, and even recorded a deterioration in the statistics. The decrease in residential independence during the times of systemic transformation was caused by a rapid decrease in the quantitative construction of multi-family housing and its level per 1000 population to the size of the early industrialization of the country. Such a decline was recorded in the years 1988-2002, when the number of households per 100 dwellings statistically increased from 111.7 to 114.6. In the countryside, this ratio increased faster (from 111.7 to 116.3) than in the cities (from 111.7 to 113.6) due to a lower percentage of migration from the rural population to cities and a departure from its intensive procreation patterns than in PRL [Cesarski M. 2011: 12]. As a result of these unfavorable changes in 2002, there were 2 million households in the cities living in dependency (i.e., together with other households in a single apartment, and in 2019 about 1.7 million Poles formed such dependent households), including 426 thousand people under 40 years of age [Cesarski M. 2011: 12, 16]. The statistical housing deficit deepened from 1.3 million in 1988 to 1.6 million in 2002. Depending on the statistical approach to calculating the housing deficit, the 'housing gap' in Poland in 2019 ranged from 641,000 to 2.1 million apartments (the latter figure also includes overcrowding and substandard apartments). 
In the second decade of the 21st century, however, there were significant changes in the quantitative development of residential buildings in Poland, which were mainly related to foreign economic emigration of the population and domination of private investors on the property market. The fast-growing real estate development sector has been recording increases in the number of apartments offered to the financially better off population for several years now. As a result, it has created a surplus of apartments over the number of households, but has not reduced the housing deficit. According to a report by the Ministry of Development at the end of 2018, there were 424,000 more apartments than households (residential and non-residential units), which indicates an increase in the number of vacancies. Treating an apartment as an investment yielding a higher return on capital than bank deposits resulted in the fact that in recent years, apartments for sale or rent have had the largest share in the real estate market (59.9\% in 2019), while the percentage of homes for own use was $38,1 \%$ in 2019 . Only $2.0 \%$ of the apartments, the construction of which began in 2019, were residential investments of municipalities, labor establishments and social housing associations that would satisfy the needs of the population with lower incomes [Efekty działalności...2018: 15].

The current failure of housing investments to meet the social needs of Poles is accompanied by a significant improvement in housing conditions compared to the previous period. This fact is reflected in the values of indicators showing the average number of rooms in an apartment, the average number of people per apartment and per room as well as the usable floor area of an apartment (see Table 1). The improvement in the quality of the housing standard results, mainly, from the increase in the wealth of the Polish society as compared to the previous period and concerns not only the new housing construction, but also the housing stock created before 1989, which increases its technical, utility and consequently market value.

Numerous flaws and deficiencies in housing construction during the PRL period should not obscure the obvious fact that the apartments created at that time meant a social advancement for millions of Poles coming from the provinces, and gave workers from the cities a sense of security and stability in life. In the interwar period, the apartments were generally overcrowded, and some of the buildings and apartments were substandard. The deficit of housing space affected the development of a number of troublesome phenomena in the living environment, such as suboccupation and staying at somebody else' place. In 1931, only $20 \%$ of the Polish 
Table 1: Selec ted indicators of the housing situation of the population in Poland in the years 1946-2018

\begin{tabular}{|l|r|r|r|r|}
\hline \multicolumn{1}{|c|}{ Category } & 1946 & 1950 & 1988 & \multicolumn{1}{c|}{2018} \\
\hline $\begin{array}{l}\text { Average number of dwellings } \\
\text { per 1,000 inhabitants }\end{array}$ & 211.0 & 234.0 & 283.0 & 380.5 \\
Average number of rooms per dwelling & 2.27 & 2.34 & 3.39 & 3.82 \\
Average number of people per dwelling & 4.73 & 4.09 & 3.46 & 2.63 \\
Average numer of people per room & 2.05 & 1.75 & 1.02 & 0.69 \\
Number of households per 100 dwellings & no data & 122.0 & 112 & $112.3^{*}$ \\
\hline
\end{tabular}

*data based on NSP from 2011.

Source: Frąckowiak M. [2008: 20, 45]; Gospodarka mieszkaniowa... [2019: 9-13].

population had access to electricity and $10 \%$ to the water supply system [Cesarski M. 2016: 128]. In the PRL period, however, the housing standard in towns and villages clearly improved. The population received a wider access to running water, central heating, a flush toilet, and gradually transmitting gas. The greatest leap in civilization with respect to equipping apartments occurred with central heating (from 4.9\% in 1950 to $72.8 \%$ in 1988), water supply system (from $19.1 \%$ in 1950 to $84.2 \%$ in 1988), and a flush toilet (from $11.5 \%$ in 1950 to $71.5 \%$ in 1988) [see Table 2]. At the end of the 1980s, however, $16 \%$ of households were still deprived of access to running water. Nevertheless, the satisfaction of the total housing needs (town/rural) showed a steady growth after the war, with the rate of growth in the equipment of apartments with basic technical and sanitary installations varying from territory to territory, which showed better development in towns than in the countryside. The enormous gap between Poland and the European standard of equipping apartments with basic installations was, largely, reduced during the communist period. As early as in the 1970s, with regard to the number of apartments that have water supply, Poland was clearly ahead of Greece and including, to a slightly lesser extent, the Iberian Peninsula countries - like Spain and Portugal. However, the national housing stock was less well equipped with installations than in Western European countries, especially in the case of sanitary facilities in bathrooms and toilets [Cesarski M. 2011: 9-10]. The country's extensive program of electrification, which resulted in the fact that by $1970,99.6 \%$ of urban dwellings and $91.9 \%$ of rural dwellings were connected to the power grid, cannot be forgotten [Frąckowiak M. 2008: 45]. The intensive electrification of rural areas between 1950 and 1970, dur- 
ing which time the share of apartments connected to the national power grid increased by almost $62 \%$., was particularly important for the country's socio-economic development. After the fall of communism, access to basic sanitary and technical facilities (mainly flush toilets and bathrooms in apartments) continued to improve, which had a positive impact on the quality of the housing stock. During this period, the processes of equalizing the disproportions in the equipment of apartments with installations between cities and rural areas also accelerated. At the end of 2018, 96.8\% of the apartments used water supply system, but the investment gap in the area of raising the standard of apartments turned out to be significant, with the statistics showing the existence of $17.4 \%$ of apartments lacking access to central heating and as much as $44.5 \%$ to gas, mainly in rural areas $(77.5 \%)$ [Raport... 2020: 13].

Table 2: Percentage of apartments equipped with sanitary and technical installations in Poland in 1950, 1988 and 2018

\begin{tabular}{|l|c|c|c|}
\hline \multicolumn{1}{|c|}{ Category } & 1950 & 1988 & 2018 \\
\hline Water conduit & 19.1 & 84.2 & 96.9 \\
Flushed lavatory & 11.5 & 71.5 & 93.8 \\
Central heating & 4.9 & 72.8 & 82.6 \\
Gas from the grid & 6.9 & 48.5 & 55.5 \\
\hline
\end{tabular}

Source: Gospodarka mieszkaniowa... [2019: 14]; Makowska M. [2013: 129]; Frąckowiak M. [2008: 45].

The pace of catching up with the richest European countries is an important measure of changes in the housing situation of Poles in recent decades. It turns out that just like at the end of the Polish People's Republic, after almost three decades of the existence of free Poland, almost all basic housing indicators differ from the average level recorded in Western European and Scandinavian countries. Thus, when calculating the number of dwellings per 1000 inhabitants, Poland achieves 385 dwellings (data for 2018), which is one of the worst results in the whole of European Union (the EU average exceeds 500 dwellings). The average usable floor area of an apartment in Poland is $75.1 \mathrm{~m}^{2}$, which places our country in the 20th position out of 24 EU countries examined (EU average: $96.4 \mathrm{~m}^{2}$ ). The gap between Poland and Western European countries is even greater with respect to usable floor area per person: in Poland, it is $28.2 \mathrm{~m}^{2}$, whereas the EU average is $41.9 \mathrm{~m}^{2}$. In 2018, the average number of chambers per per- 
son is 1.1 in Poland (occupying the last place in the EU), while the EU average is 1.7 chambers [Raport... 2020: 11].

The above-mentioned facts allow the formulation of a general conclusion that housing shortage occurs not only in a centrally managed economy, but also appears as a nodal socio-economic problem in the free market economy. This is especially so in the case of erroneously defined methods and means of action of housing policy aimed at satisfying the needs and improving the housing conditions of the population in its basic scope, both in quantitative and qualitative terms.

\section{A JOINT EFFORT OR A FOREIGN COST? THE ROLE OF THE STATE IN SATISFYING THE HOUSING NEEDS OF POLES IN THE YEARS 1944-1948}

At the outset, it should be recalled that the post-war state authorities were imposed on Poland by the USSR, which meant undemocratic rule and a loss of sovereignty for several decades. In the 1940s, the communists carried out agricultural reform (1944) and nationalized basic industries (since 1946). During this period, some freedom was left to artisanship and the cooperative movement. The period of reconstruction of the Polish state coincided with the struggle for a new political and economic system of the country.

In the opinion of the supporters of public intervention by the state, regarding post-war housing policy, with all the reservations made against it, the assessment of its implementation should be more balanced than it has been so far. This observation applies, especially, to the years 1944-1948, when the basic housing stock was being rebuilt under the conditions of low social income growth. Let us focus our attention only on this period, being aware of the dominant role of the state in construction to the end of People's Republic of Poland. At this point, the voice of criticism is focused on the methods of operation of the state apparatus, which are perceived as too radical and too close to the solutions applied in the social and economic policy of the USSR [Jarosz D. 2010: 28-9]. According to Prof. Anna Szustek, such a picture may give the impression that strong state interference in alleviating the housing deficit shortly after the war would only be the result of the communist vision of economic policy modelled on the Soviet one, which do not have the right to appear in other political con- 
ditions. But, according to the researcher, it was precisely the scale of the state's involvement in the early years following the war that was necessary due to the size and nature of the damage and the increased movement of the population. This required the implementation of fast and rigorous administrative actions. The state, in order to cope with the housing problem, had to decisively enter into the sphere of property ownership and disposal, establishing that all the apartments are public goods, which for the period of reconstruction of the housing stock are subject to the housing authority. This meant limiting the right of ownership to an apartment. The so-called renovation decree of October 26 1945, pursuant to which owners of residential real estate were obliged to demolish a residential building and repair the damaged building at their own expense. In the event of the property owner failing to fulfill this obligation, the construction authorities could demolish the damaged building and take over the construction materials obtained from the demolition or repair the building at the owner's expense [Dz.U. 1945 nr 50 poz. 281; Szustek A. 2013: 185-6].

Without entering into a polemic with the above statements, it should be noted that in post-war Europe, including the capitalist countries, such or similar actions of the state were not isolated events. It should be noted that the government's intervention during the period of economic reconstruction was of a special nature and that, under normal circumstances, the rights to housing ownership should be restored. In the case of Poland, such actions in 1945 seemed necessary and justified from the point of view of a society that had been pauperized and mentally mutilated.

The Acts on Investment Reliefs [Dz.U. 1947 nr 43 poz. 221] and support for private housing [Dz.U. $1947 \mathrm{nr} 52$ poz. 270], passed in 1947, were also to stimulate social initiative in order to, quickly, restore the housing space. These acts granted a number of tax reliefs and facilities to legal and natural persons who were active in the construction industry. However, this instrument of housing policy was in force only during the period of reconstruction and then, after the communists took full power, the state stopped supporting private construction. The question of creating the economic basis for the rational management of the housing stock was much less well resolved since it was only partially regulated by the 1948 decree on the lease of premises [Andrzejewski A. 1979: 143].

The decree of 21 December 1945 on public property management and tenancy control [Dz.U. $1946 \mathrm{nr} 4$ poz. 27] also arouses much controversy. The adversaries of this legal act see it as the main tool of State pressure to limit the right to free disposal of apartments to their owners in favour of 
the accommodation authority. Although the decree described above was not free from errors as it kept the rents for the use of apartments at a low level and even contributed, in some cases, to abuses by the housing authority, its main purpose was to make housing reserves available to people deprived of housing and livelihoods or who were ill. This included those that were necessary for the state offices and institutions as well as workplaces established at that time. It was difficult to expect private owners of houses and large apartments to voluntarily give up their surplus housing to unknown people for free or for a small rent. According to some researchers, actions based on radical state interference in housing ownership relations were justified and resulted from the difficult material situation of the population after the war [see, among others, Frąckowiak M. 2008; Andrzejewski A. 1979].

Currently, Poland is critical of the actions of the post-war State authorities in their overly hasty takeover of real estate for housing purposes in 1945 after owners who were declared dead or missing during the war. It should be recalled that in Poland, real estate owners or their possible heirs had six months to take possession of property abandoned during the war. After that period, the properties were transferred to the State Treasury as free of private claims. After 1989, the actions of the communist authorities were considered clearly illegal. Some researchers, however, interpret these facts somewhat differently. According to Prof. Anna Szustek, the accepted takeover period in Poland was not at all as short as it is now believed to have been, especially since other countries had shorter takeover periods (1.5-3 months). This scholar shares the views of a group of historians who believe that under the conditions of a devastated country the search for housing reserves in the existing stock was not to be dictated by the looting of private property in order to increase the State's income, but served to alleviate the housing shortage. Such a radical action would have been expected from any government, which intended to remain in power, regardless of the prevailing economic and political system. The illegal takeover of pre-war properties by the communist authorities is undeniable, seeing the reasons for this in the weak structures of a state under reconstruction. Illegal activities after the war are opposed to abuses in recovery proceedings that took place after 1989 in free Poland [Szustek A. 2013: 187; see incl. Siemieniako B. 2017].

It should be clearly stated that after 1948, the authorities of the People's Republic of Poland decided to continue the previously chosen course of the housing strategy, which had a subsidy and regulatory character. This 
meant the consolidation and subsequent strengthening of the State's position in the housing sector at the expense of market and cooperative entities. The solutions adopted at that time influenced the entire housing policy in Poland for the next four decades.

\section{BETWEEN THE DEGRADATION AND HUMANIZATION OF THE PRL-PERIOD HOUSING. A LOOK FROM THE PERSPECTIVE OF THE YEAR 2O2O}

The contemporary panorama of cities and, in some cases, villages is often filled with the image of multi-family housing estates of different sizes created during the times of the People's Republic of Poland. The spatial shape of these estates and the architectural designs of the buildings clearly reflects the model of reality in which they were built. After 1989, it turned out that the housing construction of that period became a permanent functional and spatial element of almost every city in Poland despite the collapse of the concept of building a "socialist city" with a dominant industrial zone in its structure. Interestingly, the voice in the discussion of urban planners, architects or planners on mass housing construction often differs from the opinions and judgments of the inhabitants of the post-PRL residential buildings themselves, which creates a certain difficulty in the general assessment of the whole phenomenon. In general, however, one critical voice coming from various circles prevails. The negative features of the housing construction of the PRL period most often include:

- low standard of furnishing and fit-out of apartments as well as, regarding the design intent, incomplete space supply of housing estates with basic social and service and commercial infrastructure equipment,

- lack of spatial order and uniformity of urban and architectural solutions resulting from the binding and thoughtlessly accepted design doctrine;

- creation of intolerant features of the living environment, related to socio-spatial disintegration and antisocial behavior of the inhabitants [Chmielewski M.J., Mirecka M. 2007: 5].

Moreover, housing construction on a scale of time, based on economic and technical criteria, is assessed in terms of the rate of wear and tear 
of residential buildings together with the accompanying infrastructure [Chmielewski M.J., Mirecka M. 2007: 5].

While there can be no criticism of the building technology used in the period of the Polish People's Republic or the standard of use of apartments, the predictions of total social and technical degradation of large housing estates following the collapse of communism in Poland have so far proven to be incorrect.

Among others, Prof. Bohdan Jałowiecki, dealing with the sociology of the city is the author of the black script announcing the disappearance of large housing complexes from the urban landscape. In the early 1990s, he assumed that blocks of flats in Central and Eastern Europe, including Poland, as was earlier the case in Western European countries, would be decapitalized after some time due to lack of investment. As a result, some of the residents of those blocks of flats will have to move to more modern residential zones, and their place will be taken over by poorer foreign workers, who will turn these places into slums over time. Therefore, as a consequence of many years of neglect, the housing estates will be demolished. B. Jałowiecki predicted that after the collapse of the People's Republic of Poland, the hard laws of the market would tip the scales to the detriment of mass housing. Due to the limitation of indirect subsidies from the state, local communities will not be able to bear the costs of maintaining the urban economy, and hence the housing economy. Local governments, especially those from post-industrial centers, which will not be able to ensure the existence of cities, will be in a similar situation [Jałowiecki B. 1995: 40-3]. The scientist's apparent pessimism about the low purchasing power of the population was probably due to his observations made during the first years of the system transformation, when Poles made the greatest sacrifices related to unemployment and high inflation, which directly translated into a temporary decrease in their disposable income. It should be noted that 30 years after the fall of communism, the processes accelerating social and technical degradation of large housing complexes were largely halted, no planned demolitions of buildings took place, and the population did not leave their living areas en masse, despite unfavorable changes in their social and professional structure [Rębowska A. 2000: 86-7]. This was determined by the scale of housing construction in the period of the Polish People's Republic and the aforementioned hard market forces, which instead of the anticipated process of deepening degradation rationalized and economized the housing management of the existing stock, which brought certain benefits (as well as certain threats) to the are- 
as previously considered problematic. Primarily, users, hosts and owners were concerned about the condition of housing estates (private ownership of apartments prevails in Poland), thanks to which it was possible largely to prevent deterioration of the social and market value of the housing stock. The increased awareness of the care for the place of residence and the gradual material improvement of part of the society made it possible to carry out the necessary renovation and modernization works on large block housing estates. In the first place, these actions were to protect housing complexes from losing their utility standard, because the durability of the large panel was determined for the period of 50-60 years of exploitation. Therefore, thermorenovation works were started all over the country, mainly consisting in thermal insulation of building walls and replacement of window and door joinery in order to improve the thermal insulation of buildings and to protect steel construction elements against weather conditions causing their corrosion. For this purpose, targeted modernization programs subsidized from EU funds were launched, among others, in the form of Funds for Thermomodernisation and Repairs, to support investors carrying out thermomodernisation and repair projects [Węcławowicz-Muzioł A. 2015: 24-5]. According to experts' opinion, modern thermorenovation ensures that residential complexes erected using the large plate system will continue to last for about 150 years. The spectre of building disasters has definitely been averted, but repair programs did not cover all housing estates. The modernized residential buildings were given a new façade, which generally improved the aesthetics of the living environment. At the beginning, however, these efforts were uncoordinated due to the use of various execution techniques and random colors, which had a negative impact on the already small architectural values of the housing estate [Chmielewski M.J., Mirecka M. 2007: 211-2]. Usually, the urban modernization is accompanied by rehabilitation activities aimed at organizing the development of open spaces and building/reconstructing technical infrastructure within housing estates. Consequently, the development of commercial services has resulted in improved access to commercial and service points in housing estates, which together with the introduction or supplementation of sports and recreation infrastructure has increased the quality of life of the residents and increased the market attractiveness of residencies. Therefore, with respect to housing estates, actions were taken to give them a "human face", which has been described by experts as the humanization of housing estates. This notion is understood as a pursuit toward improving the quality of the living environment, mainly, in 
large-plate housing complexes. According to Jan Maciej Chmielewski and Małgorzata Mirecka, the aim of the humanization of housing estates is to provide conditions for the full development of people and to meet all their needs" [Chmielewski M.J., Mirecka M. 2007: 11]. This concept, therefore, has a broader meaning than standard modernization and is aimed at analyzing the needs and preferences of the collective recipient ${ }^{1}$.

It should be noted that not all multi-family housing estates, from the period of the People's Republic of Poland, were covered by programs aimed at counteracting their technical and social degradation, hence the scope of these activities need to be extended in the nearest future. This means that economic and social problems related to this construction have not been fully solved, and among the barriers standing in the way of its fuller modernization are the lack of long-term and comprehensive strategy of actions in the modernization of block housing estates on the part of the state and the housing cooperative [Szafrańska E. 2013: 49].

\section{BETWEEN MISDIAGNOSIS AND OBJECTIVE CAUSES. PRL HOUSING POLICY IN TERMS OF SEARCHING FOR SOURCES OF THE CURRENT HOUSING CRISIS}

According to Professor Maciej Cesarski, who is generally critical of socialist housing, the shortcomings of the "residential revolution" that took place in Poland after 1989 have been exaggerated [Cesarski M. 2017: 92]. The one-sided view of the issue under observation most certainly was influenced by the opinions of experts from the early 1990s who had claimed that the main (apart from the lack of market mechanism and low social income growth), if not the only reason for the housing shortage and the housing crisis that exist today were due to the erroneous assumptions of the housing policy that were implemented from the beginning of the People's Republic of Poland [see incl. Glapiński A. 1991; Paszyński A. 1989]. However, Professor Marian Frackowiak, with the whole scale of deficiencies and defects of the pre-1989 housing construction, observed more complex causes of the post-war housing crisis, which, in his opinion, are objective and independent of the implemented housing policy. The researcher identifies these causes as including: a) high capital intensi-

${ }^{1}$ In the literature on the subject, actions for stopping the degradation of large housing estates are also referred to in terms such as revitalization and restructuring. 
ty and wear and tear of the housing stock, which in turn affects the housing situation of subsequent generations inheriting the housing stock from the previous generation - in Poland this problem is solved through the modernization of housing estates; $b$ ) changes in the professional and residential structure resulting from the rapid processes of industrialization and urbanization in PRL; c) high dynamics of population growth after 1945 found almost nowhere else in Europe. Moreover, he draws attention to other no less important objective reasons influencing the weakness of the housing economy during the period of the PRL, such as the housing gap taken over in the post-war period after the Second Republic of Poland or serious losses incurred by architects and civil engineers during the war [Frąckowiak M. 1993: 107-8; 2008: 145]. At the same time, Professor M. Frąckowiak argues that the failures of the housing policy after the collapse of the PRL result from an erroneous diagnosis explaining the source of the housing problems Poles faced in the second half of the 20th century. According to him, the housing policy of the PRL period is not the direct cause of the housing crisis in the early years of the systemic transformation, but rather the erroneously functioning system of building loans. As a remedy for these difficulties, he considers as a first action to aim at increasing rents and creating a system of financing the housing construction industry, which is properly adapted to the economic capabilities of Poles, mainly based on savings and housing funds [Frąckowiak M. 1993: 107-8; 2008: 145; Cesarski M. 2012: 20].

\section{HOUSING CONSTRUCTION OF THE PRL PERIOD IN THE OPINION OF CONTEMPORARY RESIDENTS}

The knowledge of the housing situation and needs should not take place without reference to the results of surveys recording the opinions, attitudes and housing aspirations of the population. According to Ewa Kaltenberg-Kwiatkowska, the housing needs of a given community are not simply the actual state of its material situation recorded in the form of objectified measures and indicators. The housing situation of every human being is influenced by subjective factors connected with their aspirations and values, as well as the application of various criteria and scales of evaluation in relation to their living environment. Therefore, the same reality assessed in terms of statistical measures may often differ from subjective social evaluation [Kaltenberg-Kwiatkowska E. 2005: 154]. 
Sociological research from 1995 and 2000 have already shown that the opinions of Poles regarding their own housing conditions are generally realistic and restrained. Nevertheless, it is also characteristic that Poles are often less critical of their housing conditions than the statistics show. During a period of political transformation, housing aspirations are modest - usually, they do not go beyond the state of ownership [KaltenbergKwiatkowska E. 2005: 154].

In the light of sociological studies, more than half of the residents have become accustomed to living in an environment of large housing complexes, more than $1 / 3$ of them are satisfied with their apartment, and $3 / 4$ of those surveyed feel safe in their place of residence. For example, more than $80 \%$ of the surveyed residents of housing estates in Wrocław did not consider living in blocks of flats to be socially degrading, arguing that this is the standard of living in the country and that others live alike [Borowik I. 2007: 101].

In the case of subjective evaluation of housing conditions measured according to the types of buildings in which the family lives, the CBOS survey (the Social Opinion Research Centre is a public opinion polling center established in 1982) from 2008 is interesting. Although these surveys do not give an indication of the period when the residential buildings were built, with respect to the types of housing we are interested in, most of the housing stock was built between 1950 and 1989. Thus, satisfaction/average satisfaction with the housing conditions was expressed by $89 \%$ of respondents living in multi-family buildings up to four floors (with $11 \%$ dissatisfied) and $89.8 \%$ living in multi-family buildings above four floors (10.5\% dissatisfied). On the other hand, the satisfaction of living in a detached single-family house differs slightly from the satisfaction of living in multi-family buildings ( $2.5 \%$ and $3.3 \%$ respectively). The type of building in which a family lives is also related to the material conditions of the households, which are a determinant of the housing situation of each family. The CBOS research shows that the most dissatisfied were residents of low-standard premises, such as, barracks and similar structures of that nature. At the same time, the percentage of residents of multi-family buildings up to 4 floors and above 4 floors expressing their dissatisfaction with their material situation was a minority across the entire surveyed group and amounted to $27 \%$ and $25.3 \%$ respectively [Sytuacja mieszkaniowa... 2008: 22].

In the conditions of domination of residential buildings during the PRL period, the high acceptance of the place of residence by the majority 
of Poles may be surprising as confirmed by CBOS research. For example, in a survey conducted in 2019, most respondents expressed their satisfaction with life, and the greatest satisfaction, apart from social and family relations $(84 \%)$, was given for their place of residence $(83 \%)$. In general, the positive assessment of the place of residence was consistent with a relatively high level of satisfaction with material conditions, including having an apartment (67\%) [Komunikat z badań. Zadowolenie... 2019: 1, 4]. In turn, other CBOS studies indicated that over the years 1998-2018, the housing aspirations of Poles has decreased by $14 \%$, while maintaining the basic direction of aspirations set by issues related to personal and family life as well as status and material aspirations. Hence, in recent years, the percentage of respondents declaring the satisfaction of various housing needs as the main goal of their actions in the next 5-10 years has decreased [Komunikat z badań. Aspiracje... 2018: 8]. It should be noted, however, that this type of research does not fully reflect the housing situation in Poland, which is still marked by high the level of deprivation of housing needs of many social groups (e.g. people on low incomes, young people up to 35 years old). The lack of housing and prospects for its acquisition is often the main reason for economic emigration to the West.

On the example of the empirical material presented above (but rather random, as these are attempts of opinion) we can observe the evolution of the perception of the housing issue as a social problem. At the end of the PRL, the lack of housing grew to the rank of one of the biggest social problems - if not the biggest one, which ultimately could not be fully resolved. In the period of systemic transformation, the housing issue continued to occupy an important place in the social consciousness, although it was pushed to the background by issues related to maintaining work and income liquidity. However, the gradual reduction of housing aspirations among the current groups of society is conditioned by a number of socio-economic factors, such as the structural housing deficit in the past and high real estate prices.

\section{SUMMARY}

The drawbacks and pathologies of housing from the period of the PRL do not raise any major doubts today. It should be remembered, however, that the currently available housing stock is, in the main, the material output of several generations of Poles living there under both the com- 
munist and democratic system. The general aversion to state interference in the economy and the uncritical attitude towards free market mechanisms, manifested during the period of systemic transformation (19892004), eventually led to the depreciation and negation of the importance of this legacy, which has reflected on contemporary social and scientific discourse when discussing issues related to housing and social policy. A characteristic feature of such a view is also the fact that the decision-makers of the PRL period are, basically, the only ones to blame for the current housing shortage, which seems to over simplify the problem. The housing problems of Poles during the period under analysis resulted not only from faulty solutions to the housing crisis in the period of the PRL, although they continue to affect the housing situation. But are more and more a consequence of structural failures of the current neo-liberal housing policy, which, according to Prof. M. Cesarski, is characterized by a poor development of social housing, lack of credit facility as well as shortage of building plots in cities [Cesarski M. 2018: 267].

Fortunately for some time now, rather than treating the entire period of socialism in Poland as the source of almost every social and economic problems in the country today, there have been voices in public discourses calling for a more objective assessment of individual areas of life developed during the People's Republic of Poland - after all, many of these problems only appeared or even deepened after 1989 with the systemic transformation.

The black scenarios drawn by critics of socialist housing construction have, so far, not been confirmed in reality. As indicated in the article, the social and economic importance of the housing stock created before 1989 is still significant, even though in the 1990s and later it was expected to be marginalized in the socio-spatial structure of Polish cities. So far, the view of the rapid social and technical degradation of housing estates and the resulting escape of a large part of the population to other residential districts has not been confirmed. Part of the decapitalized resource has not been demolished as in the West, on the contrary - it has been modernized and humanized. In addition, in the social consciousness, living in the housing estates made of large platelets is not considered degrading, and in opinion polls most Poles express their satisfaction with their places of residence. Although the quality of the described housing environment is relatively low, which differ from the "standards" of other types of housing construction, the "blocks of flats" are not perceived by the society today as being "bad". 
In light of what has been written above, the housing policy of the PRL period should be presented neither in terms of success, as communist propaganda did, nor in terms of total failure, given the current housing situation in Poland. The measure of the progress of this policy is the quantitative development of housing, not recorded in the entire 20th century, enabling the social advancement of a large part of the rural and working population, which meant reduction of the pre-war contrasts and class and socio-cultural disparities. It is noteworthy that the high growth of the housing mesh was achieved under conditions of low capital and technological potential of the national economy. On the other hand, the failures of the post-war housing policy include low quality of construction investments, schematic and monotony of urban-architectural presuppositions and insufficient modernization of the old housing stock.

The historiographic evaluation of the undertaken research topic is, therefore, not conclusive due to its complex and multi-faceted nature. However, there is no doubt that the way of perceiving the achievements of the housing policy of the period of the Polish People's Republic will depend on the future successes or failures of the state and social institutions in solving the still large housing problems of the Polish people.

\section{REFERENCES}

\section{Sources published}

Dz.U. 1945 nr 50 poz. 281, Dekret z dnia 26 października 1945 r. o rozbiórce i naprawie budynków zniszczonych i uszkodzonych wskutek wojny.

Dz.U. 1946 nr 4 poz. 27, Dekret z dnia 21 grudnia 1945 r. o publicznej gospodarce lokalami i kontroli najmu.

Dz.U. 1947 nr 43 poz. 221, Ustawa z dnia 2 czerwca 1947 r. o ulgach inwestycyjnych.

Dz.U. 1947 nr 52 poz. 270, Ustawa z dnia 3 lipca 1947 r. o popieraniu budownictwa.

Gospodarka mieszkaniowa i infrastruktura komunalna w 2018 roku (2019), GUS, Warszawa.

Komunikat z badań - Zadowolenie z życia (2019), GUS, Warszawa.

Komunikat z badań. Aspiracje Polaków w latach 1998, 2008, 2018 (2018), CBOS, 148, Warszawa.

Raport. Stan mieszkalnictwa w Polsce (2020), Ministerstwo Rozwoju, Warszawa.

Sytuacja mieszkaniowa gospodarstw domowych. Komunikat z badan ",Warunki życiowe społeczeństwa polskiego. Problemy i strategie" (2008), CBOS, Warszawa.

\section{Literature}

Andrzejewski A. (1977), Sytuacja mieszkaniowa w Polsce w latach 1918-1974, Państwowe Wydawnictwo Ekonomiczne, Warszawa.

Andrzejewski A. (1979), Polityka mieszkaniowa, Państwowe Wydawnictwo Ekonomiczne, Warszawa. 
Borowik I. (2007), Kierunki przemian wspótczesnego miasta - suburbanizacja oraz humanizacja blokowisk, [in:] Borowik I., Sztalta K. (eds.), Wspótczesna socjologia miasta. Wielość ogladów i kierunków badawczych dyscypliny, Wydawnictwa Uniwersytetu Wrocławskiego, Wrocław, 97-104.

Cesarski M. (2011), Mieszkanie i warunki mieszkaniowe jako wyznacznik procesów demograficznych - Polska na tle powojennej Europy Zachodniej, [in:] Osiński J. (ed.), Współczesne problemy demograficzne - rzeczywistość i mity. Ujęcie krajowe, regionalne i globalne, Oficyna Wydawnicza SGH, Warszawa, 121-142.

Cesarski M. (2012), Podejście ekonomiczne w polskim mieszkaniowym piśmiennictwie lat transformacji, Problemy Rozwoju Miast, 1, 15-26.

Cesarski M. (2016), Polityka i sytuacja mieszkaniowa w Polsce Ludowej, [in:] Grata P. (ed.), Od kwestii robotniczej do nowoczesnej kwestii socjalnej. Studia z polskiej polityki społecznej XX i XX wieku, t. IV, Wydawnictwo Uniwersytetu Rzeszowskiego, Rzeszów, 127-144.

Cesarski M. (2017), Niektóre sprzeczności neoliberalnej polityki mieszkaniowej-mechanizmy globalne i Polska, UR Journal of Humanities and Social Sciences, 3, 90-113.

Cesarski M. (2018), Polityka mieszkaniowa w Polsce po 2015 roku - bilans otwarcia, [in:] Krawczyk M. (ed.), Polska po 2015 roku - gospodarka, społeczeństwo, Oficyna Wydawnicza SGH, Warszawa, 259-277.

Chmielewski M.J., Mirecka M. (2007), Modernizacja osiedli mieszkaniowych, Oficyna Wydawnicza Politechniki Warszawskiej, Warszawa.

Frąckowiak M. (1993), Podstawowe przyczyny narastania deficytu i pogłębiania kryzysu mieszkaniowego w Polsce, Ruch Prawniczy, Ekonomiczny i Socjologiczny, LV (4), 107-117.

Frąckowiak M. (2008), Ekonomiczne i społeczne problemy polskiego mieszkalnictwa, Wydawnictwo Poznańskiego Towarzystwa Przyjaciół Nauk, Poznań.

Glapiński A. (1991), Mam klucz, Życie Gospodarcze, 27, 4-5.

Jałowiecki B. (1995), Miasto polskie - między utopia a rzeczywistościa, [in:] Starosta P. (ed.), Zbiorowości terytorialne $i$ więzi społeczne. Studia i szkice socjologiczne dedykowane Profesorowi Wactawowi Piotrowskiemu w siedemdziesiata rocznice urodzin, Wydawnictwo Uniwersytetu Łódzkiego, Łódź, 36-43.

Jarosz D. (2010), Mieszkanie się należy... Studium z peerelowskich praktyk społecznych, Oficyna Wydawnicza ASPRA-JR, Warszawa.

Kaltenberg-Kwiatkowska E. (2005), Warunki mieszkaniowe w świadomości społecznej, [in:] Frąckiewicz L. (ed.), Przeszłość i przyszłość polskiej polityki mieszkaniowej, Instytut Pracy i Spraw Socjalnych, Instytut Gospodarki Nieruchomościami, Warszawa - Katowice, 153-169.

Kasperski W. (1963), Spótdzielczość mieszkaniowa w Polsce w latach 1957-1961, Zakład Wydawnictw CRS, Warszawa.

Makowska M. (2013), Pomiędzy interwencjonizmem państwa a wolnym rynkiem. Przyczynek do dyskusji o przemianach polityki mieszkaniowej w Polsce, Społeczeństwo i Polityka, 4, 126142.

Paszyński A. (1989), Zgoda buduje, Przegląd Techniczny, 12, 5-6.

Rębowska A. (2000), Rehabilitacja „,blokowisk”, [in:] Ziobrowski Z., Jackowska-Ptaszycka D., Rębowska A., Geissler A. (eds.), Rewitalizacja, rehabilitacja, restrukturyzacja. Odnowa miast, Instytut Gospodarki Przestrzennej i Komunalnej, Oddział w Krakowie, Kraków, 85-105.

Siemieniako B. (2017), Reprywatyzując Polskę. Historia wielkiego przekrętu, Wydawnictwo Krytyki Politycznej, Warszawa.

Szafrańska E. (2013), Możliwości przekształceń wielkich osiedli mieszkaniowych w mieście postsocjalistycznym w Polsce, Studia Miejskie, 11, 39-53. 
Szustek A. (2013), „Mieszkanie się należy... Studium z peerelowskich praktyk społecznych, Dariusz Jarosz, Warszawa 2010 [review], Echa Przeszłości, 14, 179-194.

Węcławowicz-Muzioł A. (2015), Problemy mieszkaniowe Polaków a polityka mieszkaniowa, [in:] Salomon M., Węcławowicz-Muzioł A. (eds.), Mieszkalnictwo w Polsce. Analiza wybranych obszarów polityki mieszkaniowej, Fundacja Habitat for Humanity Poland, Warszawa, 1390.

Zapart J. (1999), Polityka mieszkaniowa w Polsce. Zarys przemian, Wydawnictwo Akademii Ekonomicznej im. Oskara Langego we Wrocławiu, Wrocław.

\section{Online sources:}

Efekty działalności budowlanej w 2017 roku (2018), GUS, Warszawa, https:/ / stat.gov.pl/obszary-tematyczne/przemysl-budownictwo-srodki- trwale/budownictwo/efekty-dzialal nosci-budowlanej-w-2017-roku,3,13.html, accessed: 28.8.2020.

Mieszkanie plus: 100 tys. lokali do końca roku nie będzie. Wybudowano 887 (2019), https:/ / businessinsider.com.pl/firmy/strategie/mieszkanie-plus-ile-tanich-mieszkan-na-wyna jem-powstalo-ile-jest-w-budowie/cldbxgl, accessed 4.9.2020.

Jakub Kujawa, PhD in humanities, assistant professor in the Department of Economic History of Adam Mickiewicz University in Poznan. Interests: housing policy of the XIX-XX century, industrialization of Polish lands of the XIX-XX century, sports brand in Poland, German economy of the XIX-XX century. 